\title{
Fuzzy Inferensi System pada Produksi Kerupuk Lipat
}

\author{
Chalizah Nur Khasanah ${ }^{1}$, Purnama Nuraini ${ }^{2}$ \\ ${ }^{1,2}$ Mahasiswa Program Studi Sistem Informasi, STIKOM Tunas Bangsa, Pematangsiantar \\ chalizah1818@gmail.com
}

\begin{abstract}
Crackers are one of the favorite foods of Indonesian people which are made from flour mixture mixed with flavoring ingredients. UD.Eman is one of the factories that produces folding crackers. The instability of cracker orders which are sometimes high and sometimes low makes UD. Eman difficult in determining the amount of cracker production. These problems can be solved by using the Fuzzy Tsukamoto method by using 3 fuzzy variables, namely demand [x] where, inventory [y], production [z]. From the results of research conducted can produce clarity for the production of crackers per day. If the demand for 800 packs per day and stock of 500 packs per day, 947 packs of crackers can be produced per day.
\end{abstract}

Keywords: Crackers, Fuzzy, Fuzzy Tsukamoto, Kurupuk lipat

\begin{abstract}
Abstrak
Kerupuk merupakan salah satu makanan favorit masyarakat Indonesia yang terbuat dari adonan tepung yang dicampur dengan bahan perasa. UD.Eman merupakan salah satu pabrik yang memproduksi kerupuk lipat. Ketidakstabilan pemesanan kerupuk yang terkadang tinggi dan terkadang rendah membuat UD.Eman sulit dalam menentukan jumlah produksi kerupuk. Permasalahan tersebut dapat diselesaikan dengan menggunakan metode Fuzzy Tsukamoto dengan menggunakan 3 variabel fuzzy yaitu permintaan [x] dimana persediaan [y], produksi [z]. Dari hasil penelitian yang dilakukan dapat menghasilkan kejelasan untuk produksi kerupuk perharinya. Jika dalam perharinya permintaan 800 bungkus dan persediaan 500 bungkus maka dapat dihasilkan produksi kerupuk perharinya 947 bungkus.
\end{abstract}

Kata Kunci: Kerupuk, Fuzzy Logik, Fuzzy Tsukamoto, Kurupuk lipat

\section{Pendahuluan}

Kerupuk merupakan makanan ringan yang umumnya dibuat dari adonan tepung tapioka,biasanya kerupuk juga dicampur dengan perasa udang,ikan,dan lain sebagainya. Kerupuk dibuat dengan cara mengukus adonan sampai matang,setelah itu adonan dipotong tipis-tipis, setelah itu dikeringkan dengan menggunakan sinar matahari, lalu digoreng dengan minyak goreng. Kerupuk sendiri memiliki banyak jenisnya misalnya kerupuk udang, kerupuk putih, kerupuk kulit dan masih banyak lagi jenisnya. Kerupuk lipat merupakan salah satu kerupuk yang banyak diminati oleh masyarakat indonesia, dimana kerupuk ini berwarna kuning dan memiliki cita rasa yang berbeda. Kerupuk ini juga memiliki banyak peminat sehingga banyak pabrik-pabrik yang memproduksi kerupuk lipat ini. Permintaan kerupuk lipat dikalangan masyarakat juga banyak sehingga pabrik harus memproduksi banyak kerupuk dan harus menyediakan stok kerupuk di pabriknya. UD. Eman merupakan salah satu pabrik yang memproduksi kerupuk lipat. UD. Eman ini terletak di Desa Rambung Susu Kerasaan I, Kecamatan Pematang Bandar, Kabupaten Simalungun. Kerupuk yang di produksi juga dipasarkan ke warung disekitaran desa kerasaan yang dimana permintaan kerupuk tersebut tidak menentu sehingga UD. Eman kesulitan dalam menentukan jumlah produksi perharinya. Berdasarkan permasalahan tersebut UD. Eman membutuhkan suatu sistem yang dapat memprediksi berapa jumlah kerupuk yang akan di produksi perharinya. Banyak cabang ilmu komputer yang dapat digunakan yang tergolong dalam Artificial Intelligence seperti datamining 
[1]-[7]. Berdasarkan permasalah tersebut, peneliti menggunakan menggunakan metode Fuzzy Tsukamoto untuk menyelesaikan permasalahan tersebut.

\section{Metodologi Penelitian}

Logika Fuzzy merupakan sebuah logika yang memiliki nilai kekaburan atau kesamaran (fuzzyness) antara benar dan salah. Dalam teori logika fuzzy sebuah nilai bisa bernilai benar atau salah secara bersamaan namun berapa besar kebenaran dan kesalahan suatu nilai tergantung kepada bobot keanggotaan yang dimilikinya. Dalam logika fuzzy kemungkinan nilai keanggotaan berada diantara 0 dan 1 [8].

Pada metode Fuzzy Tsukamoto, proses inferensi dilakukan dengan aturan (rule) berbentuk IF-THEN dan menggunakan operasi AND, dimana akan dipilih nilai yang lebih minimum (MIN) dari dua variabel yang ada[9]. Sebagai hasilnya, output hasil inferensi dari tiap-tiap aturan diberikan dengan tegas (crisp) berdasarkan $\alpha$ - predikat (fire strength). Hasil akhirnya diperoleh dengan menggunakan rata-rata terbobot. Misalkan ada dua variable input, yaitu $\mathrm{x}$ dan y.serta satu variable output $\mathrm{z}$. variable $\mathrm{x}$ terbagi atas dua himpunan yaitu A1 dan A2, sedangkan variable y terbagi atas himpunan B1 dan B2.. Variabel z juga terbagi atas dua himpunan yaitu $\mathrm{C} 1$ dan $\mathrm{C} 2[10]$. Rumus yang digunakan untuk mencari $\alpha$-predikat dapat digunakan fungsi implikasi yaitu rumus MIN,dapat di tyliskan sebagai berikut :

\section{$\alpha$-predikat $=\min \left[\mu_{a}(x) ; \mu_{b}(y)\right]$.}

Hasil akhir dari perhitungan Fuzzy Tsukamoto dapat diperoleh dengan cara menggunakan rumus rata-rata berbobot, yang dimana proses ini dapat mengubah kembali variabel fuzzy menjadi sebuah variabel yang nyata dengan menggunakan rumus :

$\boldsymbol{Z}$

$$
=\frac{\left(\propto-\text { predikat }_{1} * Z_{1}\right)+\left(\propto-\text { predikat }_{2} * Z_{2}\right)+\left(\propto-\text { predikat }_{3} * Z_{3}\right)+\left(\propto-\text { predikat }_{n} * Z_{n}\right)}{\propto-\text { predikat }_{1}+\propto-\text { predikat }_{2}+\propto-\text { predikat }_{3}+\propto-\text { predikat }_{n}}
$$

\section{Hasil Dan Pembahasan}

Data diambil dari permintaan,persediaan dan produksi UD.Eman perharinya. Dimana permintaan kerupuk terbesar perharinya adalah 850 bungkus dan permintaan kerupuk terkecil mencapai 750 bungkus. Sedangkan persediaan kerupuk terbesar perharinya adalah 650 bungkus dan permintaan terkecil perharinya adalah 500 bungkus. Dalam keterbatasan yang ada UD.Eman hanya dapat memproduksi paling banyak 1000 bungkus kerupuk perharinya dan hanya dapat memproduksi paling sedikit 880 bungkus kerupuk perharinya. Berapakah produksi yang harus dihasilkan perharinya, jika permintaan 800 bungkus dan persediaan 500 bungkus. Langkah - langkah penyelesaiannya yaitu:

\section{a. Fuzzyfikasi}

Terdapat 3 variabel yang akan dimodelkan menggunakan fungsi keanggotaan representasi linier, yaitu:

1. Permintaan

Fungsi yang digunakan untuk variabel permintaan adalah himpunan Turun dan Naik :

$$
\begin{gathered}
\mu x \text { [turun] }=\left\{\begin{array}{cc}
1 & x<750 \\
\frac{850-x}{850-750} & 750<x<850 \\
0 & x>850
\end{array}\right. \\
\mu x \text { [naik] }=\left\{\begin{array}{cc}
0 & x>850 \\
x-750 & 750<x<850 \\
850-750 & x<750 \\
1 & x
\end{array}\right.
\end{gathered}
$$

Nilai keanggotan himpunan turun dan naik dari variabel permintaan adalah sebagai berikut :

$$
\mu x \text { turun }[800]=\frac{850-800}{850-750}=\frac{50}{100}=0,5
$$


$\mu \mathrm{x}$ naik $[800]=\frac{800-750}{850-750}=\frac{150}{100}=1,5$

2. Persediaan

Fungsi yang digunakan untuk variabel persediaan adalah himpunan Sedikit dan Banyak :

$$
\begin{gathered}
\mu y \text { [sedikit }]=\left\{\begin{array}{cc}
1 & y<500 \\
\frac{650-y}{650-500} & 500<y<650 \\
0 & y>650
\end{array}\right. \\
\mu y \text { [banyak] }=\left\{\begin{array}{cc}
0 & y>650 \\
\frac{y-500}{650-500} & 500<y<650 \\
1 & y<500
\end{array}\right.
\end{gathered}
$$

Nilai keanggotan himpunan sedikit dan banyak dari variabel persediaan adalah sebagai berikut :

$$
\begin{aligned}
& \mu y \text { sedikit }[550]=\frac{650-550}{650-500}=\frac{100}{150}=0,666666667 \\
& \mu y \text { banyak }[550]=\frac{550-500}{650-500}=\frac{50}{150}=0,333333333
\end{aligned}
$$

3. Produksi

Fungsi yang digunakan untuk variabel persediaan adalah himpunan Berkurang dan Bertambah :

$$
\begin{gathered}
\mu z \text { [berkurang] }=\left\{\begin{array}{cc}
1 & z<880 \\
\frac{1000-z}{1000-880} & 880<z<1000 \\
0 & z>1000
\end{array}\right. \\
\mu z \text { [bertambah] }=\left\{\begin{array}{cc}
0 & z>1000 \\
\frac{z-880}{1000-880} & 880<z<1000 \\
1 & z<880
\end{array}\right.
\end{gathered}
$$

\section{b. Pembentukan Fuzzy Rule}

Dalam pembuatan fuzzy rule, penulis membuat 4 rule untuk menyelesaikan masalah diatas, yang dibuat dalam bentuk table sebagai berikut :

\begin{tabular}{cccc}
\hline Rule & Permintaan & Persediaan & Produksi \\
\hline 1 & Turun & Banyak & Berkurang \\
2 & Turun & Sedikit & Berkurang \\
3 & Naik & Banyak & Bertambah \\
4 & Naik & Sedikit & Bertambah \\
\hline
\end{tabular}

\section{c. Perhitungan}

Perhitungan yang digunakan untuk mencari nilai $\alpha$ - predikat adalah sebagai berikut :

Rule 1 :

$$
\begin{array}{ll}
\alpha-\text { predikat } & =\min (0,5 ; 0,333333333) \\
\mathrm{z} & =0,333333333 \\
0,333333333 & =\frac{1000-x}{1000-880} \\
0,333333333 & =\frac{1000-x}{120} \\
1000-\mathrm{x}=0,333333333 \times 120 \\
1000-\mathrm{x}=40 & \\
-\mathrm{x} & =1000-40 \\
-\mathrm{x} & =960
\end{array}
$$




\section{Rule 2 :}

$$
\begin{array}{ll}
\alpha-\text { predikat } & =\min (0,5 ; 0,666666667) \\
\mathrm{Z} & =0,5 \\
0,5 & =\frac{1000-x}{1000-880} \\
0,5 & =\frac{1000-x}{120} \\
1000-\mathrm{x}=0,5 \times & 120 \\
1000-\mathrm{x}=60 & \\
-\mathrm{x} & =1000-60 \\
-\mathrm{x} & =940
\end{array}
$$

\section{Rule 3 :}

$$
\begin{array}{ll}
\alpha-\text { predikat } & =\min (1,5 ; 0,333333333) \\
\mathrm{z} & =0,333333333 \\
0,333333333 & =\frac{x-880}{1000-880} \\
0,333333333 & =\frac{x-880}{120} \\
\mathrm{x}-880 & =0,333333333 \times 120 \\
\mathrm{x}-880 & =40 \\
\mathrm{x} & =880+40 \\
\mathrm{x} & =920
\end{array}
$$

\section{Rule 4:}

$$
\begin{array}{ll}
\alpha-\text { predikat } & =\min (1,5 ; 0,666666667) \\
\mathrm{Z} & =0,666666667 \\
0,666666667 & =\frac{x-880}{1000-880} \\
0,6666666667 & =\frac{x-880}{120} \\
\mathrm{x}-880 & =0,666666667 \times 120 \\
\mathrm{x}-880 & =80 \\
\mathrm{x} & =880+80 \\
\mathrm{x} & =960
\end{array}
$$

\section{d. Defuzzyfikasi}

Perhitungan defuzzyfikasi masalah di atas adalah sebagai berikut:

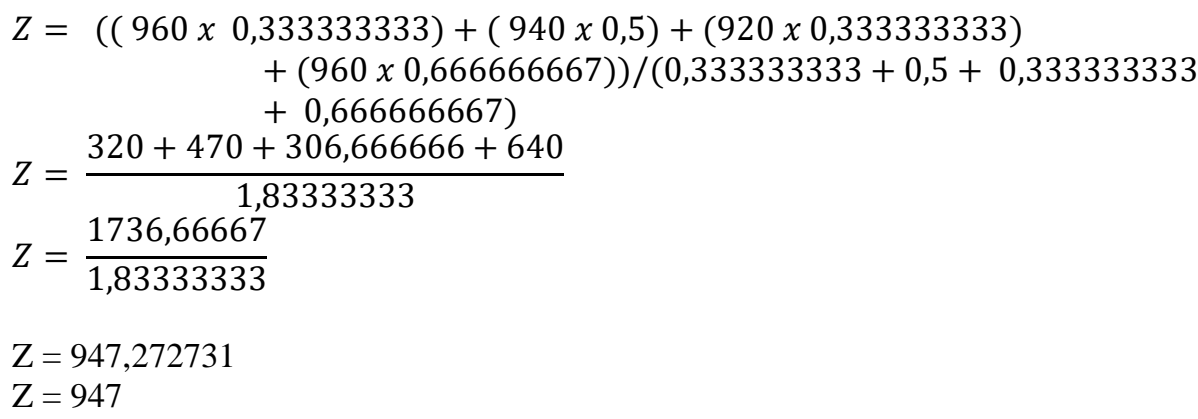

Berdasarkan perhitungan permasalahan di atas dapat disimpulkan bahwa UD. Eman dapat memproduksi 947 bungkus kerupuk perharinya.

\section{Kesimpulan}

Berdasarkan permasalahan diatas dapat disimpulkan bahwa dalam menentukan hasil produksi kerupuk UD. Eman dapat menggunakan metode Fuzzy Tsukamoto. Dari hasil perhitungan yang telah dilakukan dapat disimpulkan bahwa jika permintaan perharinya 
800 bungkus kerupuk dan persedian digudang perharinya hanya 500 bungkus maka jumlah produksi UD. Eman bisa mencapai 947 bungkus dalam sehari. Dari hasil penelitian ini dapat membuat UD .Eman semakin mudah untuk menghitung jumlah produksi kerupuknya.

\section{Daftar Pustaka}

[1] W. Katrina, H. J. Damanik, F. Parhusip, D. Hartama, A. P. Windarto, and A. Wanto, "C.45 Classification Rules Model for Determining Students Level of Understanding of the Subject," J. Phys. Conf. Ser., vol. 1255, no. 12005, pp. 1-7, 2019, doi: 10.1088/1742-6596/1255/1/012005.

[2] M. Widyastuti, A. G. Fepdiani Simanjuntak, D. Hartama, A. P. Windarto, and A. Wanto, "Classification Model C.45 on Determining the Quality of Custumer Service in Bank BTN Pematangsiantar Branch," J. Phys. Conf. Ser., vol. 1255, no. 12002, pp. 1-6, 2019, doi: 10.1088/1742-6596/1255/1/012002.

[3] Sudirman, A. P. Windarto, and A. Wanto, "Data mining tools | rapidminer: Kmeans method on clustering of rice crops by province as efforts to stabilize food crops in Indonesia," IOP Conf. Ser. Mater. Sci. Eng., vol. 420, no. 1, 2018, doi: 10.1088/1757-899X/420/1/012089.

[4] R. W. Sari, A. Wanto, and A. P. Windarto, "Implementasi Rapidminer Dengan Metode K-Means (Study Kasus: Imunisasi Campak Pada Balita Berdasarkan Provinsi)," KOMIK (Konferensi Nas. Teknol. Inf. dan Komputer), vol. 2, no. 1, pp. 224-230, 2018, doi: 10.30865/komik.v2i1.930.

[5] N. Rofiqo, A. P. Windarto, and D. Hartama, "Penerapan Clustering Pada Penduduk Yang Mempunyai Keluhan Kesehatan Dengan Datamining K-Means," KOMIK (Konferensi Nas. Teknol. Inf. dan Komputer), vol. 2, no. 1, pp. 216-223, 2018, doi: 10.30865/komik.v2i1.929.

[6] M. G. Sadewo, A. P. Windarto, and A. Wanto, "Penerapan Algoritma Clustering Dalam Mengelompokkan Banyaknya Desa/Kelurahan Menurut Upaya Antisipasi/ Mitigasi Bencana Alam Menurut Provinsi Dengan K-Means," KOMIK (Konferensi Nas. Teknol. Inf. dan Komputer), vol. 2, no. 1, pp. 311-319, 2018, doi: 10.30865/komik.v2i1.943.

[7] D. Hartama, A. Perdana Windarto, and A. Wanto, "The Application of Data Mining in Determining Patterns of Interest of High School Graduates," J. Phys. Conf. Ser., vol. 1339, no. 1, 2019, doi: 10.1088/1742-6596/1339/1/012042.

[8] W. Sahara, E. W. Sari, P. Mai, and S. Tarigan, "Fuzzy Inference System pada Produksi Kerupuk Mie Bulat," no. September, pp. 235-240, 2019.

[9] N. Novita, "Metode Fuzzy Tsukamoto Untuk Menentukan Beasiswa," vol. 1, pp. 51-54, 2019.

[10] P. Meilina, N. Rosanti, and N. Astryani, "Produksi Barang Dengan Metode Fuzzy Tsukamoto Berbasis Android," no. November, pp. 1-2, 2017. 